\title{
Nanomaterials in the Context of Type 2 Immune Responses-Fears and Potentials
}

\author{
Martin Himly, Robert Mills-Goodlet, Mark Geppert and Albert Duschl* \\ Division of Allergy and Immunology, Department of Molecular Biology, University of Salzburg, Salzburg, Austria
}

The type 2 immune response is an adaptive immune program involved in defense against parasites, detoxification, and wound healing, but is predominantly known for its pathophysiological effects, manifesting as allergic disease. Engineered nanoparticles (NPs) are non-self entities that, to our knowledge, do not stimulate detrimental type 2 responses directly, but have the potential to modulate ongoing reactions in various ways, including the delivery of substances aiming at providing a therapeutic benefit. We review, here, the state of knowledge concerning the interaction of NPs with type 2 immune responses and highlight their potential as a multifunctional platform for therapeutic intervention.

Lucio Roberto Cancado Castellano, Federal University of Paraiba,

Brazil

Reviewed by:

Krzysztof Guzik,

Jagiellonian University, Poland

Pasquale Maffia,

University of Glasgow, UK

Ilaria Puxeddu,

University of Pisa, Italy

Joelma Rodrigues Souza,

Federal University of Paraiba, Brazil

${ }^{*}$ Correspondence:

Albert Duschl

albert.dusch/@sbg.ac.at

Specialty section: This article was submitted to Inflammation,

a section of the journal

Frontiers in Immunology

Received: 28 December 2016 Accepted: 05 April 2017

Published: 25 April 2017

Citation:

Himly M, Mills-Goodlet R, Geppert M and Duschl A (2017) Nanomaterials

in the Context of

Type 2 Immune Responses - Fears and Potentials.

Front. Immunol. 8:471. doi: 10.3389/fimmu.2017.00471
Keywords: allergy, immunomodulation, immunotherapy, nanomedicine, nanoparticles, parasite infection, vaccine, wound healing

\section{NANOMATERIALS AND TYPE 2 IMMUNE RESPONSES}

Upon contact with non-self entities, the adaptive immune system decides between one of three response programs. The tolerance program, orchestrated by regulatory $\mathrm{T}$ cells $\left(\mathrm{T}_{\mathrm{reg}}\right)$, ensures that no defense is initiated against harmless agents. If pathogens are identified, the adaptive immunity chooses between two main types of defensive responses (1). The first branch, a type 1 response, is characterized by the rapid removal of pathogens by macrophages and neutrophils, mediated by $\mathrm{T}$ helper $1\left(\mathrm{~T}_{\mathrm{H}} 1\right)$ and $\mathrm{T}_{\mathrm{H}} 17$ cells, which release pro-inflammatory cytokines, such as interferon (IFN)- $\gamma$ and interleukin (IL)-12. Type 1 responses are integrated seamlessly with inflammatory reactions. The role of inflammation and type 1 responses in the context of exposure to nanoparticles (NPs) is discussed elsewhere in this volume.

The second defensive branch, type 2 immunity, involves the key cytokines IL-4, IL-5, IL-13, and different types of immune cells, such as basophils, eosinophils, mast cells, anti-inflammatory (M2) macrophages, and $\mathrm{T}_{\mathrm{H}} 2$ cells (1). This type of response is often connected to parasitic infections, later stages of the wound healing process, and to chronic inflammatory conditions, such as asthma and allergy (2). Of note, some NPs are known to modulate type 2 immune responses (3). This review covers applications of NPs in the context of type 2 immune responses, such as parasitic infections, wound healing, and allergy, with a special focus on therapeutic approaches.

\section{PARASITIC INFECTIONS}

Ancestral populations can be assumed to have been constantly subjected to parasite infections. Hence, macroparasites have played a large role in the evolution of type 2 immune responses. One particular purpose of type 2 responses is to limit the parasite load and is done so, via immunoglobulin (Ig)E type antibodies and effector cells (4). Parasitic diseases continue to be a serious health problem in 
large areas of the world (5). Unfortunately, there are currently no studies regarding coexposure to parasites and nanomaterials. However, nanomedical approaches have been investigated for vaccination, diagnosis, and therapy of parasitic diseases (6-8). Some studies have looked specifically at a shift between type 1 and type 2 responses, as indicated by characteristic cytokines and antibody isotypes. In particular, numerous nanomedical studies concerning malaria have been performed, including studies about the response type (7). For example, self-assembled protein NPs were used to vaccinate mice with Plasmodium sp. antigens, resulting in the development of protective type 2 responses (9).

In contrast, chondroitin nanocapsules upregulate $\mathrm{T}_{\mathrm{H}} 1$ cytokines and downregulate $\mathrm{T}_{\mathrm{H}} 2$ cytokines in hamsters, leading to enhanced doxorubicin-induced apoptosis that eradicates infection with Leishmania donovani (10). Similarly, the host response of mice against L. donovani was supported by artemisinin-loaded NPs that shifted the cytokine profile from type 2 to type 1 (11). This corresponds to the conventional view that Leishmania, like other microparasites, is promoted by type 2 responses and controlled by type 1 responses. However, it should be borne in mind that careful analysis of this mouse model has revealed that the prototypic $\mathrm{T}_{\mathrm{H}} 2$ cytokines IL- 4 and IL-13 can contribute to either the control or the exacerbation of disease (12). It is, thus, not always clear which role type 2 responses play in relation to specific parasites. NP adjuvants contribute to effective vaccination of mice against Angiostrongylus costaricensis and of pigs against Trichinella spiralis, but they do this by supporting a type 1 response in the first case and a type 2 response in the second $(13,14)$. Altogether, it is clear that NPs can influence the type of immune response toward a challenge, with either detrimental or protective effects for the host.

\section{WOUND HEALING}

Wound healing is a natural process that repairs and regenerates damaged tissues, for example, in the skin (15), lung (16), or intestine (17). Numerous therapies have been developed to accelerate this process, involving, for example, pharmaceutics, stem cells, electrical stimulation, negative pressure, light, or radiation $(15,18-21)$. Furthermore, NPs, especially those with antimicrobial properties, are considered as valuable tools in accelerating the wound-healing process (22). Silver (Ag) was used for its antibacterial properties since the Roman empire, and nowadays, numerous therapeutical products containing ionic Ag or Ag NPs are on the market $(22,23)$. Several publications review the beneficial effects of ionic nanoparticulate Ag in wound healing $(22,24,25)$. An earlier animal study by Tian et al. (26) showed that Ag NPs accelerate healing and improve cosmetic appearance of wounds in a dose-dependent manner. By analyzing bacterial growth and cytokine profiles in wound sections, the authors demonstrated the antimicrobial and anti-inflammatory potential of Ag NPs. Microbially synthesized Ag NPs enhanced woundhealing efficiacy in rats $(11,27,28)$. Using a transforming growth factor (TGF) $\beta$ receptor inhibitor, $\mathrm{Li}$ and coworkers proposed the activation of the TGF- $\beta 1 /$ Smad signaling pathway as a mechanism of wound-healing enhancement by polyvinylalcohol/chitosan oligosaccharide Ag nanofibers (29).
Gold (Au) NPs were successful in acceleration of wound healing in combination with photobiomodulation therapy in rats (15) or in combination with the antioxidants epigallocatechin gallate (EGCG) and $\alpha$-lipoic acid (ALA) in mice (30). The observed decrease of CD68 expression and increase of SOD1 expression around the wound area suggest that anti-inflammatory as well as antioxidative effects of the Au NP/EGCG/ALA mixture play a role in increased wound-healing efficiency (30). The inflammatory reaction in wounded skin of rats was investigated in a recent report. Phytochemically stabilized Au NPs accelerate wound healing in a process that involves alteration of the amounts of TGF- $\beta 1$, vascular endothelial growth factor (VEGF), and the number of mast cells in the wounded skin sections compared to vehicle controls $(31,32)$. These observations indicate an involvement of the particles in type 2 immune functions during the healing process. A different approach for wound healing with $\mathrm{Au}$ NPs in diabetic mice, showed that spherical nucleic acid-Au NP conjugates efficiently to downregulate target genes in diabetic mice. Thus, resulting in full wound closure occurring within 12 days, compared to control wounds which were only $50 \%$ closed (33).

Aside from $\mathrm{Ag}$ and $\mathrm{Au}$, other types of NPs, such as selenium (34), zinc oxide (35), copper oxide $(36,37)$, iron oxide $(38)$, or polymeric NPs (39), were shown to be beneficial for wound healing (Table 1). Thereby, the beneficial effect is either a result of the NPs properties alone (i.e., antibacterial effects) or a combined result of the NPs with other substances. For example, $\mathrm{TiO}_{2} \mathrm{NPs}$ have been shown to enhance the wound-healing potential of chitosan (40), which is used as wound dressing material (41) and is currently commercially available (42). Some caution may be necessary when using very high concentrations of chitosan leading to a highly positively charged NP surface, as recently demonstrated in a study involving Au NPs (43). Increased uptake by phagocytic cells and an enhanced pro-inflammatory response were determined, rendering chitosan coating exceeding an optimal range counteractive for wound healing. Chitosan-based copper nanocomposites accelerate wound healing in rats by modulation of different cytokines and growth factors. The upregulation of VEGF, TGF- $\beta 1$, and IL- 10 as well as the downregulation of tumor necrosis factor $\alpha$ (TNF- $\alpha$ ) indicate a shift toward type 2 immunity. An interesting approach using biodegradable NPs was published by Galili (44), who demonstrated that $\alpha$-Gal NPs can accelerate the process of wound healing. The mechanism involves binding of natural anti- $\alpha$-Gal antibodies to the multiple $\alpha$-Gal epitopes, which then present on the NPs resulting in complement activation, recruitment, and activation of macrophages, which leads to tissue regeneration $(44,45)$. A summary of current therapeutic approaches for NPs is given in Table $\mathbf{1}$.

\section{ALLERGY}

Allergy and asthma represent a global public health concern in developed countries, with a steady increase also occuring in emerging countries. According to the World Health Organization, approximately 300 million people worldwide are currently suffering from asthma, with a rising trend to increase up to 400 million by 2025 (85). Allergic diseases include the various forms 
TABLE 1 | Selected therapeutic nanoparticle (NP)-based approaches in the context of type 2 immune responses at different stages of development.

\begin{tabular}{|c|c|c|}
\hline Nanomaterial type & Therapeutic benefits & Reference \\
\hline \multicolumn{3}{|l|}{ In clinical practice } \\
\hline \multicolumn{3}{|l|}{ Inorganic NPs } \\
\hline Silver & $\begin{array}{l}\text { Most widely used NPs in wound healing due to their antimicrobial and anti-inflammatory properties. } \\
\text { Several products already on the market }\end{array}$ & $(22-24,26$ \\
\hline \multicolumn{3}{|l|}{ Organic/biodegradable NPs } \\
\hline Glatiramer acetate & Prolonged onset and reduced transition from relapsing remitting to progressive multiple sclerosis & $(46,47)$ \\
\hline Lipids & T cell inhibition and immunosuppression by encapsulating sirolimus into nanostructured lipid carriers & $(48)$ \\
\hline \multicolumn{3}{|l|}{ In clinical studies } \\
\hline \multicolumn{3}{|l|}{ Organic/biodegradable NPs } \\
\hline L-leucin-L-glutamate copolymers & Enhanced depot effect for insulin upon subcutaneous injection & (49) \\
\hline Polyethylene glycol (PEG) & Anti-tumor necrosis factor $\alpha$ antibody fragment against rheumatoid arthritis and Crohn's disease & $(50)$ \\
\hline Calcium phosphate & Enhanced depot effects for various drugs & $(51)$ \\
\hline Poly-L-lysine dendrimer & Antimicrobial protection from genital herpes and HIV infection & $(52)$ \\
\hline Virus-like particles (VLPs) & $\begin{array}{l}\text { VLPs derived from Qbeta bacteriophages filled with CpG-DNA and filled with house dust mite extract, } \\
\text { respectively, conjugated with Der } p 1 \text { peptide }\end{array}$ & $(53,54)$ \\
\hline
\end{tabular}

\section{In development/basic research studies}

Inorganic NPs

Gold

Cerium oxide

Selenium

Zinc oxide

Copper oxide

Iron oxide

Titanium dioxide

Fullerene

Silica

Carbon nanotubes (CNTs)

Organic/biodegradable NPs

Chondroitin

Polyglutamic acid (PGA)

Poly-D,L-lactic-co-glycolic acid (PLGA)

Polymethylvinyl ether-co-maleic anhydride (PVM-MA)
Successful acceleration of wound healing in combination with photobiomodulation therapy, antioxidants, or nucleic acids

Phytochemically stabilized Au NPs accelerate wound healing altering the amounts of transforming growth factor

Plasmodium falciparum antigen Pfs25 or Yersinia pestis F1

Acceleration of the wound-healing process by enhancement of the proliferation and migration of fibroblasts,

keratinocytes, and vascular endothelial cells

Shortening of healing duration of artificial wounds in Wistar rats

Castor oil/chitosan-modified ZnO NPs increase wound-healing efficacy in rats

Enhanced wound-healing activity of CuO NPs by inhibiting pathogenic bacteria surviving in the wound sites

Acceleration of wound healing by chitosan-based copper nanocomposites involves a type 2 shift of immune response

Thrombin-conjugated magnetic $\gamma-\mathrm{Fe}_{2} \mathrm{O}_{3}$ NPs enhance wound healing in rats

Reeducation of TAMs from M2 toward M1 phenotype by FDA-approved ferumoxytol

$\mathrm{TiO}_{2}$ NPs enhance wound-healing potential of chitosan

Induction of dendritic cells (DCs) maturation and activation of $\mathrm{T}_{\mathrm{H}} 1$ immune response using $\left[\mathrm{Gd} @ \mathrm{C}_{82}(\mathrm{OH})_{22}\right]_{n}$ fullerene NPs

Boost of vaccine immune response against influenza virus

Lysozyme-loaded mesoporous silica NPs (nanopollens) with long-term antibacterial effects tested in ex vivo small intestine models

Plasmodium vivax AMA-1 N-terminus peptide-CNT conjugate delayed parasitemia in infected Plasmodium berghei mouse model

Doxorubicin-loaded chrondroitin nanocapsules eradicate infection with Leishmania donovani in hamsters

Timothy grass pollen extract-loaded PGA NPs as delivery vehicle to DCs

Inhibition of $\mathrm{T}_{\mathrm{H}} 2$ immune response and airway inflammation in mice

Treatment for autoimmune disease by induction of antigen-specific tolerance using myelin bound to NPs glioma model

$\mathrm{CpG} /$ peanut extract-PLGA enhance peanut-specific immunotherapy

Bet $v$ 1-loaded PLGA NPs improve efficacy of allergen-specific immunotherapy (AIT) by downregulating ongoing $\mathrm{T}_{\mathrm{H}} 2$ response in mouse models

Ole e 1-loaded PLGA (<2 $\mu \mathrm{m})$ microparticles as vehicle for AIT

Oral administration of major Chenopodium album pollen allergen Che a 3-PLGA downregulates $\mathrm{T}_{\mathrm{H}} 2$ response in mouse model

Artemisinin-loaded PLGA NPs showed superior antileishmanial efficacy compared to free artemisinin in a mouse model and shifted cytokine profile from type 2 to type 1

Successful M cell targeting with birch pollen allergen-loaded PLGA NPs specifically functionalized with Aleuria aurantia lectin

Ryegrass pollen extract-loaded PVM-MA NPs as adjuvant for AIT 


\begin{tabular}{|c|c|c|}
\hline Nanomaterial type & Therapeutic benefits & Reference \\
\hline \multirow[t]{2}{*}{ PEG } & $\begin{array}{l}\text { Self-assembled PEG-dendrimer efficiently delivered and increase anti-inflamatory effect of dexamethasone in } \\
\text { allergic airways inflammation }\end{array}$ & $(74,75)$ \\
\hline & $\begin{array}{l}\text { pH-sensitive PEG nanocarriers for grass pollen and house dust mite allergen encapsulation and controlled } \\
\text { release from DCs }\end{array}$ & \\
\hline \multirow[t]{5}{*}{ Chitosan } & Local nasal AIT with house dust mite-chitosan vaccine in mouse asthma model & $(76-80)$ \\
\hline & $\begin{array}{l}\text { Intranasal AIT with immunodominant Der p } 1 \text { epitope reduced allergen-specific T cell reactivity and interleukin } \\
\text { (IL)4 and IL5 levels in brochnoalveolar fluid of sensitized mice }\end{array}$ & \\
\hline & Oral DNA vaccine of house dust mite allergen Der $p 1$ formulated with chitosan NPs & \\
\hline & Induction of $T_{H} 1$ immune response by DNA vaccine of Der $p 2$ with chitosan NPs & \\
\hline & $\begin{array}{l}\text { Oral gene delivery of chitosan-formulated NPs in peanut-allergic mouse model with additional induction } \\
\text { of mucosal dimeric allergen-specific immunoglobulin A }\end{array}$ & \\
\hline Polyanhydride NPs & $\begin{array}{l}\text { Intradermal immunization of mice with polyanhydride NPs loaded with peanut proteins induced strong } \\
\text { mixed } T_{H} 1 / T_{H} 2 \text { immune response (immunostimulant) }\end{array}$ & $(81)$ \\
\hline Polyacrylic acid & Antibacterial activity of poly-phospoester-based Ag-loaded NPs in lung infections & $(82)$ \\
\hline \multirow[t]{2}{*}{ Protamine NPs } & $\begin{array}{l}\text { Liposome-protamine-DNA NPs induced strong } T_{H} 1 \text { response upon subcutaneous AIT in Chenopodium album- } \\
\text { sensitized mouse model }\end{array}$ & $(83,84)$ \\
\hline & $\begin{array}{l}\text { Protamine-based NPs (proticles) with CpG complexed with Ara h } 2 \text { extracted from raw peanuts induced } \\
\text { strong } T_{H} 1 \text { response upon subcutaneous AIT in mice }\end{array}$ & \\
\hline Self-assembled protein NPs (SAPN) & $\begin{array}{l}\text { SAPN used to vaccinate mice with Plasmodium sp. antigens achieved delayed parasite motility and } \\
\text { complement lysis }\end{array}$ & (9) \\
\hline $\begin{array}{l}\text { Immunostimulatory complexes } \\
\text { (ISCOMs) }\end{array}$ & $\begin{array}{l}\text { Effective intranasal immunization of mice against Angiostrongylus costaricensis with ISCOM formed by a } \\
\text { synthetic pph } 1 \text { peptide linked to cholera toxin adjuvanted with saponin/phospholipids/cholesterol NPs }\end{array}$ & $(14)$ \\
\hline$\alpha$-Gal NPs & $\begin{array}{l}\text { Tissue regeneration induced by macrophages activated through binding of natural anti- } \alpha \text {-Gal antibodies } \\
\text { to multiple } \alpha \text {-Gal epitopes present on the NPs }\end{array}$ & $(44,45)$ \\
\hline
\end{tabular}

of asthma, rhinitis, conjunctivitis, angioedema, urticaria, eczema, eosinophilic disorders, such as esophagitis and life-threatening anaphylaxis, as in the case of food, insect venom, or drug allergies. Patients with allergic diseases have a significantly reduced quality of life, and even milder forms such as allergic rhinitis have a significant economic impact (86). Globally, allergic diseases affect $20-30 \%$ of the population, and in the developed countries sensitization rates of up to $50 \%$ have been reported (87).

Allergy is defined by IgE reacting specifically with nonpathogenic environmental proteins, thus, being defined as allergens (88). Presence of allergen-specific IgE in the blood of affected individuals resulting from an overshooting $\mathrm{T}_{\mathrm{H}} 2$-driven immune response, is hence the hallmark of being sensitized (89). The sensitization process is intiated upon first contact where a variety of potential functions of allergens may be involved (90-98); however, the overall mechanism of allergic sensitization still remains to be fully established. As potential risk factors, nutrition, and hygiene have been described (99). Upon second contact with the allergen, specific IgE-loaded allergic effector cells, i.e., tissue-resident mast cells and peripheral blood basophils, degranulate due to IgE receptor cross-linking and release vasoactive mediators (histamine, tryptase, etc.). During this process, being termed the effector function, the typical allergic symptoms emerge, including vasodilation and permeation resulting in swelling, itching, and redness, characteristic of the wheal and flare reaction in rhinoconjunctivitis. Furthermore, effector cells initiate the secretion of lipid mediators (leukotrienes) and cyto-/ chemokines leading to bronchoconstriction, mucus production, intestinal hypermotility, as in the case of more severe forms, such as anaphylaxis (88). Furthermore, eosinophil infiltration, chronicity, and amplification of the allergic response can lead to tissue remodeling, a characteristic of asthma (100).

Presently, few studies investigating the potential sensitizationaggravating effects of particulate matter itself or NP-associated allergens exist (101-103). Historically, research was conducted on combustion-derived particles as reviewed recently $(104,105)$. The interaction of allergens with engineered NPs, such as Au, $\mathrm{Ag}, \mathrm{ZnO}, \mathrm{TiO}_{2}, \mathrm{SiO}_{2}$, may arise at sites where such materials are handled, so risk of disease-aggravating conditions can be expected in occupational settings. Studies in mice have addressed the pro-allergic potential of $\mathrm{Au}, \mathrm{TiO}_{2}$, and $\mathrm{SiO}_{2} \mathrm{NPs}$ in contact hypersensitivity. Such reactions are characterized by a $\mathrm{T}$ cellmediated delayed-type adverse response without the presence of allergen-specific IgE or airway hyperresponsiveness with eosinophil infiltration, mucous cell metaplasia, and elevated type 2 cytokine secretion (106-108). Graphene nanosheets and multiwalled carbon nanotubes (MWCNTs) have been shown to induce a $\mathrm{T}_{\mathrm{H}} 2$ immune response in mouse models when administered intravenously (109). While in human in vitro studies including fullerene or MWCNTs contrasting results were reported $(110,111)$. Human skin-derived mast cells and peripheral blood basophils exhibited a significant inhibition of IgE-dependent mediator release by fullerene. Furthermore, MWCNTs were shown to inhibit allergen-induced type 2 cytokine secretion by peripheral blood mononuclear cells from house dust mite-allergic individuals, emphasizing the pro-inflammatory potential of MWCNTs which has recently been reviewed (112). In line with these reports, MWCNTs have been shown to suppress humoral immune effects in mice by a mechanism involving the activation of cyclooxygenases in the spleen in response to signals from 
lung (113). Accordingly, iron oxide NPs were shown to attenuate serum levels of OVA-specific $\operatorname{IgG}_{1}$ and $\operatorname{IgG}_{2 \mathrm{a}}$ in mice (114). Protein corona formation represents a paradigm when studying the biological effects of NPs and it is well accepted that protein-NP interactions may alter the proteins' 3D structure and hence epitope integrity (115). In the context of type 2 immune effects, IgE epitope integrity is essential. Following this rationale, allergic disease-modulating effects were investigated upon interaction of three major inhalant allergens with Au NPs (116). This study showed that increased, decreased, or similar allergenic responses may be observed, presumably depending on the orientation and accessibility of the IgE epitopes of the allergens bound to the NPs.

Not only material composition has an influence on the type of immune response but the particle size of the same material can also be decisive upon inducing either a type 1 or a type 2 immune response. Bigger particles $(>100 \mathrm{~nm})$ are more prone to induce a type 2 response, in comparison to smaller particles $(\sim 50 \mathrm{~nm})$ that rather induce a type 1 response $(117,118)$. Wen et al. showed that NPs were also able to induce both a $T_{H} 1$ and a $T_{H} 2$ response equally when using chitosan NPs in combination with ovalbumin in mice (119). The immune responses elicited by different NPs can be diverse and are highly dependent on material and size of the particles.

During the past two decades much progress has been made in the field of molecule-based diagnostics, also termed componentresolved diagnostics (CRD), with the development of two types of serological tests involving purified natural or recombinantly produced allergen molecules, coated to particles (ImmunoCAPTM) or a glass surface (ISAC ${ }^{\mathrm{TM}}$ ) (120-122). The higher predictive value of CRD compared to extract-based methods has been appreciated by clinicians $(123,124)$. These two large studies advocate that CRD improves the decision-making process during the prescription of allergen-specific immunotherapy (AIT) due to its high specificity. AIT has been described $>100$ years ago and still remains the only effective treatment against allergy resulting in a shift from a type 2 immune response toward a tolerogenic state, which is characterized by the key cytokines IFN- $\gamma$, IL-10, and TGF- $\beta$ and production of allergen-specific $\operatorname{IgG}_{4}$ blocking antibodies (125-127). The potential of NPs being used for allergen therapeutics emerged from adjuvants which will be discussed next.

\section{ADJUVANTS}

The idea to use adjuvants to aid in vaccination was established due to the finding that a higher specific antibody titer can be induced by an abscess at the site of inoculation (128, 129). Adjuvants comprise different classes of compounds, including microbial substances, mineral salts, emulsions, or microparticles, displaying potentiating and/or modulating effects on the human immune system, and they have even been quoted as "dirty little secrets of immunologists" $(130,131)$. The main desired effects of adjuvants in therapy or vaccination can be broken down into two groups. On the one hand they function as delivery vehicles of the active pharmaceutical ingredient (API) to antigen-presenting cells (APCs), like dendritic cells (DCs) and macrophages. On the other hand, they induce an immune potentiation effect that is achieved by activation of the APCs through specific receptors, thus creating an inflammatory context (132). Adjuvants have to be safe in formulation, stable during storage, easily expelled from the body, either by being biodegradable or by efficient excretion, and furthermore, the costs of their production should to be low (133).

Aluminum hydroxide or alum has been in use as an adjuvant from as early as 1926 (134), widely used in vaccination ever since (135). Its clinical function also involves innate mechanisms established for recognition of crystals based on NLRP3 inflammasome activation (136). In the last two decades, the research into new adjuvants has increased, but many new adjuvants fall prey to local or systemic toxicity and are not suitable for the use in humans (137). A possible new approach is the use of nanosized inorganic or organic particles as an efficient antigen delivery vehicle $(138,139)$. Additional advantages of using NPs as adjuvants are that they can incorporate several desired effects of an adjuvant in one substance. They may (i) confer a depot function with enhanced abundance in the tissue/circulation, (ii) function as a delivery vehicle by binding the APIs and delivering them to the APCs, and (iii) be able to induce immunostimulatory effects (140). It has been demonstrated that different kinds of NPs ranging from inorganic NPs, like silica $(60,141)$ and gold $(142)$, over lipids (143) to biodegradable polymeric particles $(144,145)$ show adjuvant potential. For some NPs the adjuvant effect is greater than that of alum $(138,141,146)$.

Due to their unique properties, NPs readily bind substances like proteins, peptides, and nucleic acid vaccines (147). Those conjugates have been shown to be taken up by APCs $(146,148)$, and thus NPs are able to deliver the APIs to the APCs. The immune stimulatory effect of NPs has been shown, for example, using poly- $\boldsymbol{\gamma}$-glutamic acid NPs and DCs (148), which facilitates the second major requirement for adjuvants-to provide a costimulatory signal for initiation of an immune response. Keeping all that in mind, several types of NPs bear the potential to act as efficient adjuvants in formulation.

\section{NPs-A POTENTIAL MULTIFUNCTIONAL PLATFORM FOR INTERACTIONS WITH THE IMMUNE SYSTEM}

In addition to spontaneous interactions of proteins (or other biological substances) with NPs, engineered nanomaterials may form a platform where various functions of different chemical entities may be combined intentionally (Figure 1). It should be stated here that in particular for nanomedical approaches the strict nano definition by "ISO/TS27687:2008 NanotechnologiesTerminology and definitions for nanoobjects-NP, nanofibre and nanoplate" confining NPs for a size range up to $100 \mathrm{~nm}$ is often relaxed. Therefore, nanomedicines usually list substances of particulate matter in the submicro size range. The surface of NPs can be functionalized covalently with specific ligands including antibodies and fragments thereof or other immunologically active proteins, such as allergens. Other ligands may include peptides, nucleic acids such as immunostimulatory CpG-DNA, small inhibitory (si-)RNAs, aptamers, carbohydrates, and other 


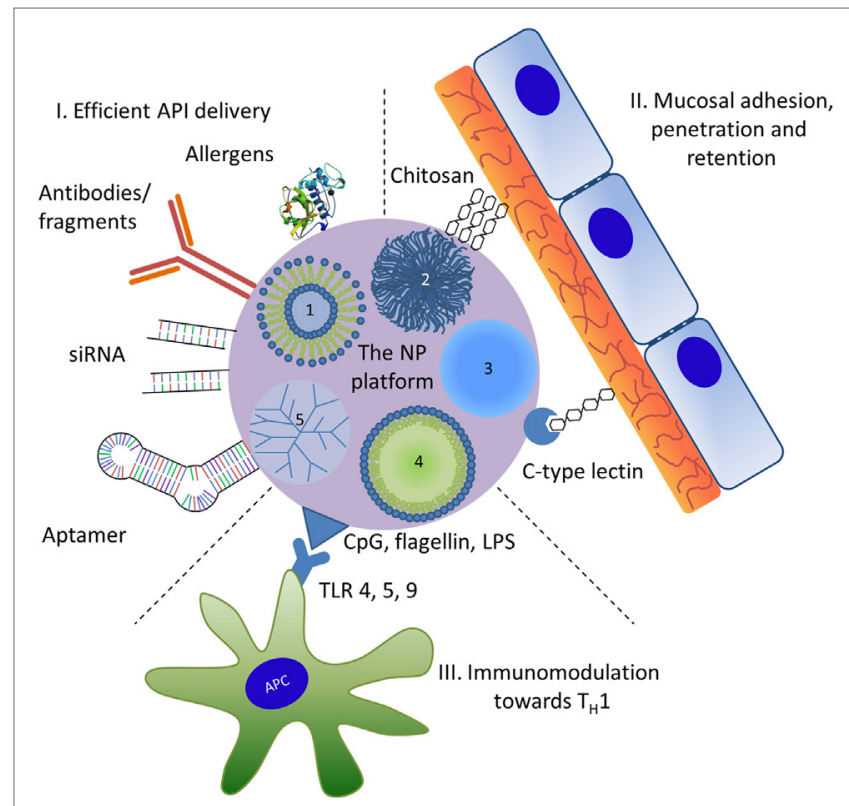

FIGURE 1 | Nanoparticles (NPs) used as a potential multifunctional nanomedical platform to facilitate three roles in therapeutic use. The numbers represent different types of NPs: 1, liposomes; 2, biopolymers; 3, inorganic NPs; 4, nanoemulsions; 5, dendrimers. Active pharmaceutical ingredient (API); for symbolizing protein APIs the 3D structure of Der $p 1$, the major house dust mite allergen (PDB entry $3 f 5 v$ ) was used; LPS, lipopolysaccharide; TLR, Toll-like receptor; $T_{H} 1$, $T$ helper 1 cells.

biomolecules [vitamin $\mathrm{D}_{3}$ or toll-like receptor (TLR) ligands]. Such NP conjugates may mediate (i) efficient delivery, i.e., cellular targeting and uptake, (ii) mucosal adhesion, penetration, and retention, or (iii) immunostimulatory or modulatory effects. Applied in a well-controlled manner, these ligands modify and can thus be used to opimize the safety profile, specificity, and efficacy of a vaccine candidate.

\section{NPs Mediate Efficient Delivery}

Anticytokine therapy has been recognized since the early 2000s $(149,150)$, and a number of approaches are in the clinic or the pipeline. Examples include antibodies to counteract the effects of TNF- $\alpha$ or IL- $1 \beta$ in inflammatory bowel disease, rheumatoid arthritis, psoriatic arthritis, ankylosing spondylitis, and atherosclerosis. Such antibodies work via shifting the immune response from $\mathrm{T}_{\mathrm{H}} 1$ or $\mathrm{T}_{\mathrm{H}} 17$ toward $\mathrm{T}_{\mathrm{H}} 2(151,152)$. Polyethylene glycol has been regarded as a nanomedical proponent which due to its nondegradable properties under physiological conditions confers a prolonged circulation time of the co-delivered API $(153,154)$. During AIT, clinical efficacy of a vaccine has to be counterbalanced by a well-defined safety profile of the whole formulation, i.e., API and adjuvant (155). Therefore, the "hypoallergen concept" emerged where substances with reduced IgE-binding capacities were used. By genetic engineering or chemical modification (allergoids) the IgE-binding epitopes were disrupted, and hence, higher amounts could be administered at lower risk of sidereactions (156-162).

\section{NPs Enable Mucosal Adhesion, Tissue Retention, and Penetration}

Among the aforementioned ligands, carbohydrates may establish specific as well as non-specific interactions with the human immune system. Therefore, these hydrophilic moieties represent attractive functionalizations for enhanced mucosal delivery via the oral, nasal, or dermal routes of application. Upon adhesion with the mucosal or intradermal tissue, prolonged retention may result in a more effective presentation to immunocompetent cells in the dedicated lymphoid tissues $(163,164)$. Using NPs as a platform for additionally introducing mucoadhesive ligands can improve sublingual AIT, which have been shown effective in ovalbumin-sensitized mouse models (165-169). Table 1 provides a list of potential candidate approaches based on specific (upon binding to lectins) and non-specific (upon hydrophilic interactions of chitosan with mucins) carbohydrate recognition aiming at enhanced efficacy of AIT.

\section{NPs for Immunostimulation and Modulation toward $T_{\mathrm{H}} \mathbf{1}$}

The response of the immune system against internal or external stimuli can be categorized into two reactions, stimulation or suppression (170). It is possible to push the response either to stimulation or suppression, and this regulation can be used in therapeutic treatment $(171,172)$. An immune stimulation may be desired for increasing vaccination or cancer treatment efficacy. On the contrary, undesired effects of immune stimulation can result from interactions of leukocytes with NPs (173-175). These may include IFN response, lymphocyte activation, and cytokine storm, leading to severe off-target effects limiting the therapeutic efficacy. Immunosuppression, as observed for inhaled MWCNTs in a mouse model (113), is desired for treatment of hypersensitivities like allergies or autoimmune diseases or in the context of organ transplantation for preventing organ rejection $(172,176,177)$. The downside of suppression is that it may lead to an attenuated defense state of the body facilitating infections and cancerous diseases.

The interactions with NPs do not only lead to stimulation or suppression of the immune response but also influence the type of immune response. Both the ability to deviate an immune response from a type 2 to a type 1 response as well as a bias for different types of responses have been described for NPs. Reeducation of tumor-associated macrophages from M2 toward M1 phenotype by NP-mediated induction of pro-inflammatory responses was found effective using the FDA-approved iron oxide NP compound ferumoxytol (58). Similar effects were observed with rabies virus glycoprotein peptide-loaded paclitaxel-carrying biodegradable poly-D,L-lactic-co-glycolic acid (PLGA) NPs in a mouse glioma model, and notably, even crossing of the bloodbrain barrier was achieved $(66,178)$. These polarizing effects may be due to an uptake preference reported for type 2 compared to type 1 macrophages (179). A modulation in immune response was observed using PLGA NPs which were able to downregulate an ongoing $\mathrm{T}_{\mathrm{H}} 2$ response in an allergic $\mathrm{BALB} / \mathrm{c}$ mouse model (68). Additionally, PLGA NPs have been used to induce a $\mathrm{T}_{\mathrm{H}} 1$ response when delivering the $T_{H}$ 2-biased peptide hepatitis $B$ 
surface antigen (180). A potential therapeutic use for PLGA NPs coated with CpG-DNA (TLR9 ligand) and peanut extract was demonstrated when peanut-allergic mice treated with the NPs were protected from anaphylaxis upon challenge and lower levels of $\mathrm{T}_{\mathrm{H}} 2$ cytokines were measured compared to untreated mice (67). Other possible candidate ligands acting as danger signals providing immunodeviation into type 1 include lipopolysaccharide, monophosphoryl lipid-A, cholera or E. coli toxins, or flagellin (181-187). Table 1 gives an overview on nanomedical immunomodulatory approaches in particular in respect to AIT, which have recently been reviewed elsewhere (188).

\section{CONCLUDING REMARKS}

As for other mechanisms of the immune system (inflammation, type 1 response, tolerance), NPs can modulate type 2 responses in different ways. It is a task for the community, working at the border between immunology and nanotechnology, to understand the parameters leading to NP induced up- or downregulation of

\section{REFERENCES}

1. Gause WC, Wynn TA, Allen JE. Type 2 immunity and wound healing: evolutionary refinement of adaptive immunity by helminths. Nat Rev Immunol (2013) 13(8):607-14. doi:10.1038/nri3476

2. Oliphant CJ, Barlow JL, McKenzie ANJ. Insights into the initiation of type 2 immune responses. Immunology (2011) 134(4):378-85. doi:10.1111/j.13652567.2011.03499.x

3. Dobrovolskaia MA, Shurin M, Shvedova AA. Current understanding of interactions between nanoparticles and the immune system. Toxicol Appl Pharmacol (2016) 299:78-89. doi:10.1016/j.taap.2015.12.022

4. Fitzsimmons CM, Falcone FH, Dunne DW. Helminth allergens, parasitespecific IgE, and its protective role in human immunity. Front Immunol (2014) 5:61. doi:10.3389/fimmu.2014.00061

5. Hotez PJ, Alvarado M, Basanez MG, Bolliger I, Bourne R, Boussinesq M, et al. The global burden of disease study 2010: interpretation and implications for the neglected tropical diseases. PLoS Negl Trop Dis (2014) 8(7):e2865. doi:10.1371/journal.pntd.0002865

6. Romero EL, Morilla MJ. Nanotechnological approaches against Chagas disease. Adv Drug Deliv Rev (2010) 62(4-5):576-88. doi:10.1016/j.addr.2009.11.025

7. Aditya NP, Vathsala PG, Vieira V, Murthy RSR, Souto EB. Advances in nanomedicines for malaria treatment. Adv Colloid Interface Sci (2013) 201:1-17. doi:10.1016/j.cis.2013.10.014

8. Torres-Sangiao E, Holban AM, Gestal MC. Advanced nanobiomaterials: vaccines, diagnosis and treatment of infectious diseases. Molecules (2016) 21(7):E867. doi:10.3390/molecules21070867

9. McCoy ME, Golden HE, Doll TA, Yang Y, Kaba SA, Zou X, et al. Mechanisms of protective immune responses induced by the Plasmodium falciparum circumsporozoite protein-based, self-assembling protein nanoparticle vaccine. Malar J (2013) 12:136. doi:10.1186/1475-2875-12-136

10. Chaurasia M, Pawar VK, Jaiswal AK, Dube A, Paliwal SK, Chourasia MK. Chondroitin nanocapsules enhanced doxorubicin induced apoptosis against leishmaniasis via Th1 immune response. Int J Biol Macromol (2015) 79:27-36. doi:10.1016/j.ijbiomac.2015.04.043

11. Want MY, Islamuddin M, Chouhan G, Ozbak HA, Hemeg HA, Dasgupta AK, et al. Therapeutic efficacy of artemisinin-loaded nanoparticles in experimental visceral leishmaniasis. Colloids Surf B Biointerfaces (2015) 130:215-21. doi:10.1016/j.colsurfb.2015.04.013

12. Hurdayal R, Brombacher F. The role of IL-4 and IL-13 in cutaneous leishmaniasis. Immunol Lett (2014) 161(2):179-83. doi:10.1016/j.imlet.2013.12.022

13. Deville S, Pooter A, Aucouturier J, Laine-Prade V, Cote M, Boireau P, et al. Influence of adjuvant formulation on the induced protection of mice type 2 responses. Understanding of such concepts could enable the prediction of the outcomes of human exposure to NPs.

\section{AUTHOR CONTRIBUTIONS}

All four authors were involved in concept drafting, literature screening, design of display items, writing, and editing of the paper.

\section{FUNDING}

The authors gratefully acknowledge financial support by the International PhD Program "Immunity in Cancer and Allergy" of the Austrian Science Fund (FWF, grant No: W1213), the European Community's Seventh Framework Program (FP7/2007-2013) under grant agreement No: 263147 (NanoValid-Development of reference methods for hazard identification, risk assessment, and LCA of engineered nanomaterials), and the PLUS AllergyCancer-BioNano (ACBN) Research Center. immunized with total soluble antigen of Trichinella spiralis. Vet Parasitol (2005) 132(1-2):75-80. doi:10.1016/j.vetpar.2005.05.029

14. Solano-Parada J, Gonzalez-Gonzalez G, Torro LM, dos Santos MF, Espino AM, Burgos M, et al. Effectiveness of intranasal vaccination against Angiostrongylus costaricensis using a serine/threonine phosphatase $2 \mathrm{~A}$ synthetic peptide and recombinant antigens. Vaccine (2010) 28(32):5185-96. doi:10.1016/j.vaccine. 2010.05.072

15. Lau P, Bidin N, Islam S, Shukri WN, Zakaria N, Musa N, et al. Influence of gold nanoparticles on wound healing treatment in rat model: photobiomodulation therapy. Lasers Surg Med (2016). doi:10.1002/1sm.22614

16. Gardner A, Borthwick LA, Fisher AJ. Lung epithelial wound healing in health and disease. Expert Rev Respir Med (2010) 4(5):647-60. doi:10.1586/ers.10.62

17. Iizuka M, Konno S. Wound healing of intestinal epithelial cells. World J Gastroenterol (2011) 17(17):2161-71. doi:10.3748/wjg.v17.i17.2161

18. Haubner F, Ohmann E, Pohl F, Strutz J, Gassner HG. Wound healing after radiation therapy: review of the literature. Radiat Oncol (2012) 7:162. doi:10.1186/ 1748-717X-7-162

19. Jackson WM, Nesti LJ, Tuan RS. Mesenchymal stem cell therapy for attenuation of scar formation during wound healing. Stem Cell Res Ther (2012) 3(3):20. doi:10.1186/scrt111

20. Thakral G, Lafontaine J, Najafi B, Talal TK, Kim P, Lavery LA. Electrical stimulation to accelerate wound healing. Diabet Foot Ankle (2013) 4. doi:10.3402/ dfa.v4i0.22081

21. Huang C, Leavitt T, Bayer LR, Orgill DP. Effect of negative pressure wound therapy on wound healing. Curr Probl Surg (2014) 51(7):301-31. doi:10.1067/ j.cpsurg.2014.04.001

22. Das $\mathrm{S}, \mathrm{Baker} \mathrm{AB}$. Biomaterials and nanotherapeutics for enhancing skin wound healing. Front Bioeng Biotechnol (2016) 4:82. doi:10.3389/fbioe.2016.00082

23. Konop M, Damps T, Misicka A, Rudnicka L. Certain aspects of silver and silver nanoparticles in wound care: a minireview. J Nanomater (2016). doi:10.1155/ 2016/7614753

24. Wilkinson LJ, White RJ, Chipman JK. Silver and nanoparticles of silver in wound dressings: a review of efficacy and safety. J Wound Care (2011) 20(11):543-9. doi:10.12968/jowc.2011.20.11.543

25. Oyarzun-Ampuero F, Vidal A, Concha M, Morales J, Orellana S, MorenoVilloslada I. Nanoparticles for the treatment of wounds. Curr Pharm Des (2015) 21(29):4329-41. doi:10.2174/1381612821666150901104601

26. Tian J, Wong KK, Ho CM, Lok CN, Yu WY, Che CM, et al. Topical delivery of silver nanoparticles promotes wound healing. ChemMedChem (2007) 2(1):129-36. doi:10.1002/cmdc.200600171

27. Pourali P, Razavian Zadeh N, Yahyaei B. Silver nanoparticles production by two soil isolated bacteria, Bacillus thuringiensis and Enterobacter cloacae, and 
assessment of their cytotoxicity and wound healing effect in rats. Wound Repair Regen (2016) 24(5):860-9. doi:10.1111/wrr.12465

28. Pourali P, Yahyaei B. Biological production of silver nanoparticles by soil isolated bacteria and preliminary study of their cytotoxicity and cutaneous wound healing efficiency in rat. J Trace Elem Med Biol (2016) 34:22-31. doi:10.1016/ j.jtemb.2015.11.004

29. Li CW, Wang Q, Li J, Hu M, Shi SJ, Li ZW, et al. Silver nanoparticles/chitosan oligosaccharide/poly(vinyl alcohol) nanofiber promotes wound healing by activating TGFbeta1/Smad signaling pathway. Int J Nanomedicine (2016) 11:373-86. doi:10.2147/IJN.S91975

30. Leu JG, Chen SA, Chen HM, Wu WM, Hung CF, Yao YD, et al. The effects of gold nanoparticles in wound healing with antioxidant epigallocatechin gallate and alpha-lipoic acid. Nanomedicine (2012) 8(5):767-75. doi:10.1016/ j.nano.2011.08.013

31. Kim JE, Lee J, Jang M, Kwak MH, Go J, Kho EK, et al. Accelerated healing of cutaneous wounds using phytochemically stabilized gold nanoparticle deposited hydrocolloid membranes. Biomater Sci (2015) 3(3):509-19. doi:10.1039/ c4bm00390j

32. Lee J, Kim J, Go J, Lee JH, Han DW, Hwang D. Transdermal treatment of the surgical and burned wound skin via phytochemical-capped gold nanoparticles. Colloids Surf B Biointerfaces (2015) 135:166-74. doi:10.1016/j.colsurfb. 2015.07.058

33. Randeria PS, Seeger MA, Wang XQ, Wilson H, Shipp D, Mirkin CA, et al. siRNA-based spherical nucleic acids reverse impaired wound healing in diabetic mice by ganglioside GM3 synthase knockdown. Proc Natl Acad Sci U S A (2015) 112(18):5573-8. doi:10.1073/pnas.1505951112

34. Ramya S, Shanmugasundaram T, Balagurunathan R. Biomedical potential of actinobacterially synthesized selenium nanoparticles with special reference to anti-biofilm, anti-oxidant, wound healing, cytotoxic and anti-viral activities. J Trace Elem Med Biol (2015) 32:30-9. doi:10.1016/j.jtemb.2015.05.005

35. Diez-Pascual AM, Diez-Vicente AL. Wound healing bionanocomposites based on castor oil polymeric films reinforced with chitosan-modified $\mathrm{ZnO}$ nanoparticles. Biomacromolecules (2015) 16(9):2631-44. doi:10.1021/acs. biomac.5b00447

36. Gopal A, Kant V, Gopalakrishnan A, Tandan SK, Kumar D. Chitosan-based copper nanocomposite accelerates healing in excision wound model in rats. Eur J Pharmacol (2014) 731:8-19. doi:10.1016/j.ejphar.2014.02.033

37. Sankar R, Baskaran A, Shivashangari KS, Ravikumar V. Inhibition of pathogenic bacterial growth on excision wound by green synthesized copper oxide nanoparticles leads to accelerated wound healing activity in Wistar Albino rats. J Mater Sci Mater Med (2015) 26(7):214. doi:10.1007/s10856-015-5543-y

38. Ziv-Polat O, Topaz M, Brosh T, Margel S. Enhancement of incisional wound healing by thrombin conjugated iron oxide nanoparticles. Biomaterials (2010) 31(4):741-7. doi:10.1016/j.biomaterials.2009.09.093

39. Nurhasni H, Cao J, Choi M, Kim I, Lee BL, Jung Y, et al. Nitric oxide-releasing poly(lactic-co-glycolic acid)-polyethylenimine nanoparticles for prolonged nitric oxide release, antibacterial efficacy, and in vivo wound healing activity. Int J Nanomedicine (2015) 10:3065-80. doi:10.2147/IJN.S82199

40. Archana D, Dutta J, Dutta PK. Evaluation of chitosan nano dressing for wound healing: characterization, in vitro and in vivo studies. Int J Biol Macromol (2013) 57:193-203. doi:10.1016/j.ijbiomac.2013.03.002

41. Jayakumar R, Prabaharan M, Kumar PTS, Nair SV, Tamura H. Biomaterials based on chitin and chitosan in wound dressing applications. Biotechnol Adv (2011) 29(3):322-37. doi:10.1016/j.biotechadv.2011.01.005

42. Brown MA, Daya MR, Worley JA. Experience with Chitosan dressings in a Civilian Ems System. J Emerg Med (2009) 37(1):1-7. doi:10.1016/j.jemermed. 2007.05.043

43. Boyles MS, Kristl T, Andosch A, Zimmermann M, Tran N, Casals E, et al. Chitosan functionalisation of gold nanoparticles encourages particle uptake and induces cytotoxicity and pro-inflammatory conditions in phagocytic cells, as well as enhancing particle interactions with serum components. J Nanobiotechnology (2015) 13:84. doi:10.1186/s12951-015-0146-9

44. Galili U. Acceleration of wound healing by alpha-gal nanoparticles interacting with the natural anti-Gal antibody. J Immunol Res (2015) 2015:589648. doi:10.1155/2015/589648

45. Galili U. Anti-Gal: an abundant human natural antibody of multiple pathogeneses and clinical benefits. Immunology (2013) 140(1):1-11. doi:10.1111/ imm. 12110
46. Duda PW, Schmied MC, Cook SL, Krieger JI, Hafler DA. Glatiramer acetate $\left(\right.$ Copaxone $\left.{ }^{\circledast}\right)$ induces degenerate, Th2-polarized immune responses in patients with multiple sclerosis. JClin Invest (2000) 105(7):967-76. doi:10.1172/ JCI8970

47. Comi G, Martinelli V, Rodegher M, Moiola L, Bajenaru O, Carra A, et al. Effect of glatiramer acetate on conversion to clinically definite multiple sclerosis in patients with clinically isolated syndrome (PreCISe study): a randomised, double-blind, placebo-controlled trial. Lancet (2009) 374(9700):1503-11. doi:10.1016/S0140-6736(09)61259-9

48. Yu Q, Hu X, Ma Y, Xie Y, Lu Y, Qi J, et al. Lipids-based nanostructured lipid carriers (NLCs) for improved oral bioavailability of sirolimus. Drug Deliv (2016) 23(4):1469-75. doi:10.3109/10717544.2016.1153744

49. Chan Y-P, Meyrueix R, Kravtzoff R, Soula O, Soula G. Basulin, a long-acting formulation of human insulin based on medusa nanoparticles. Nanobiotechnology (2005) 1(3):317-8. doi:10.1007/s12030-005-0061-5

50. Fleischmann R, Vencovsky J, van Vollenhoven RF, Borenstein D, Box J, Coteur G, et al. Efficacy and safety of certolizumab pegol monotherapy every 4 weeks in patients with rheumatoid arthritis failing previous diseasemodifying antirheumatic therapy: the FAST4WARD study. Ann Rheum Dis (2009) 68(6):805-11. doi:10.1136/ard.2008.099291

51. Masson JD, Thibaudon M, Belec L, Crepeaux G. Calcium phosphate: a substitute for aluminum adjuvants? Expert Rev Vaccines (2016) 16:289-99. doi:10.1080/14760584.2017.1244484

52. Moscicki AB, Kaul R, Ma Y, Scott ME, Daud II, Bukusi EA, et al. Measurement of mucosal biomarkers in a phase 1 trial of intravaginal 3\% StarPharma LTD 7013 gel (VivaGel) to assess expanded safety. J Acquir Immune Defic Syndr (2012) 59(2):134-40. doi:10.1097/QAI.0b013e31823f2aeb

53. Kundig TM, Senti G, Schnetzler G, Wolf C, Prinz Vavricka BM, Fulurija A, et al. Der $\mathrm{p} 1$ peptide on virus-like particles is safe and highly immunogenic in healthy adults. J Allergy Clin Immunol (2006) 117(6):1470-6. doi:10.1016/j. jaci.2006.01.040

54. Senti G, Johansen P, Haug S, Bull C, Gottschaller C, Muller P, et al. Use of A-type $\mathrm{CpG}$ oligodeoxynucleotides as an adjuvant in allergen-specific immunotherapy in humans: a phase I/IIa clinical trial. Clin Exp Allergy (2009) 39(4):562-70. doi:10.1111/j.1365-2222.2008.03191.x

55. Gregory AE, Williamson ED, Prior JL, Butcher WA, Thompson IJ, Shaw AM, et al. Conjugation of Y. pestis F1-antigen to gold nanoparticles improves immunogenicity. Vaccine (2012) 30(48):6777-82. doi:10.1016/j.vaccine. 2012.09.021

56. Kumar R, Ray PC, Datta D, Bansal GP, Angov E, Kumar N. Nanovaccines for malaria using Plasmodium falciparum antigen Pfs25 attached gold nanoparticles. Vaccine (2015) 33(39):5064-71. doi:10.1016/j.vaccine.2015.08.025

57. Chigurupati S, Mughal MR, Okun E, Das S, Kumar A, McCaffery M, et al. Effects of cerium oxide nanoparticles on the growth of keratinocytes, fibroblasts and vascular endothelial cells in cutaneous wound healing. Biomaterials (2013) 34(9):2194-201. doi:10.1016/j.biomaterials.2012.11.061

58. Zanganeh S, Hutter G, Spitler R, Lenkov O, Mahmoudi M, Shaw A, et al. Iron oxide nanoparticles inhibit tumour growth by inducing pro-inflammatory macrophage polarization in tumour tissues. Nat Nanotechnol (2016) 11(11):986-94. doi:10.1038/nnano.2016.168

59. Yang D, Zhao Y, Guo H, Li Y, Tewary P, Xing G, et al. [Gd@C82(OH)22]n nanoparticles induce dendritic cell maturation and activate Th1 immune responses. ACS Nano (2010) 4(2):1178-86. doi:10.1021/nn901478z

60. Russell RF, McDonald JU, Lambert L, Tregoning JS. Use of the microparticle nanoscale silicon dioxide as an adjuvant to boost vaccine immune responses against influenza virus in neonatal mice. J Virol (2016) 90(9):4735-44. doi:10.1128/JVI.03159-15

61. Song H, Ahmad Nor Y, Yu M, Yang Y, Zhang J, Zhang H, et al. Silica nanopollens enhance adhesion for long-term bacterial inhibition. J Am Chem Soc (2016) 138(20):6455-62. doi:10.1021/jacs.6b00243

62. Yandar N, Pastorin G, Prato M, Bianco A, Patarroyo ME, Lozano JM. Immunological profile of a Plasmodium vivax AMA-1 N-terminus peptidecarbon nanotube conjugate in an infected Plasmodium berghei mouse model. Vaccine (2008) 26(46):5864-73. doi:10.1016/j.vaccine.2008.08.014

63. Broos S, Lundberg K, Akagi T, Kadowaki K, Akashi M, Greiff L, et al. Immunomodulatory nanoparticles as adjuvants and allergen-delivery system to human dendritic cells: implications for specific immunotherapy. Vaccine (2010) 28(31):5075-85. doi:10.1016/j.vaccine.2010.05.004 
64. Smarr CB, Yap WT, Neef TP, Pearson RM, Hunter ZN, Ifergan I, et al. Biodegradable antigen-associated PLG nanoparticles tolerize Th2-mediated allergic airway inflammation pre- and postsensitization. Proc Natl Acad Sci U S A (2016) 113(18):5059-64. doi:10.1073/pnas.1505782113

65. Hunter Z, McCarthy DP, Yap WT, Harp CT, Getts DR, Shea LD, et al. A biodegradable nanoparticle platform for the induction of antigen-specific immune tolerance for treatment of autoimmune disease. ACS Nano (2014) 8(3):2148-60. doi:10.1021/nn405033r

66. Zou L, Tao Y, Payne G, Do L, Thomas T, Rodriguez J, et al. Targeted delivery of nano-PTX to the brain tumor-associated macrophages. Oncotarget (2017) 8(4):6564-78. doi:10.18632/oncotarget.14169

67. Srivastava KD, Siefert A, Fahmy TM, Caplan MJ, Li X-M, Sampson HA. Investigation of peanut oral immunotherapy with $\mathrm{CpG} /$ peanut nanoparticles in a murine model of peanut allergy. J Allergy ClinImmunol (2016) 138(2):536-43.e4. doi:10.1016/j.jaci.2016.01.047

68. Schöll I, Weissenböck A, Förster-Waldl E, Untersmayr E, Walter F, Willheim M, et al. Allergen-loaded biodegradable poly(D,L-lactic-co-glycolic) acid nanoparticles down-regulate an ongoing Th2 response in the BALB/c mouse model. Clin Exp Allergy (2004) 34(2):315-21. doi:10.1111/j.1365-2222. 2004.01884.x

69. Scholl I, Kopp T, Bohle B, Jensen-Jarolim E. Biodegradable PLGA particles for improved systemic and mucosal treatment of Type I allergy. Immunol Allergy Clin North Am (2006) 26(2):349-364,ix. doi:10.1016/j.iac.2006.02.007

70. Batanero E, Barral P, Villalba M, Rodriguez R. Biodegradable poly (DL-lactide glycolide) microparticles as a vehicle for allergen-specific vaccines: a study performed with Ole e 1, the main allergen of olive pollen. J Immunol Methods (2002) 259(1-2):87-94. doi:10.1016/S0022-1759(01)00497-5

71. Salari F, Varasteh AR, Vahedi F, Hashemi M, Sankian M. Down-regulation of Th2 immune responses by sublingual administration of poly (lactic-co-glycolic) acid (PLGA)-encapsulated allergen in BALB/c mice. Int Immunopharmacol (2015) 29(2):672-8. doi:10.1016/j.intimp.2015.09.011

72. Roth-Walter F, Scholl I, Untersmayr E, Fuchs R, Boltz-Nitulescu G, Weissenbock A, et al. $\mathrm{M}$ cell targeting with Aleuria aurantia lectin as a novel approach for oral allergen immunotherapy. J Allergy Clin Immunol (2004) 114(6):1362-8. doi:10.1016/j.jaci.2004.08.010

73. Gomez S, Gamazo C, San Roman B, Grau A, Espuelas S, Ferrer M, et al. A novel nanoparticulate adjuvant for immunotherapy with Lolium perenne. J Immunol Methods (2009) 348(1-2):1-8. doi:10.1016/j.jim.2009.06.005

74. Kenyon NJ, Bratt JM, Lee J, Luo J, Franzi LM, Zeki AA, et al. Self-assembling nanoparticles containing dexamethasone as a novel therapy in allergic airways inflammation. PLoS One (2013) 8(10):e77730. doi:10.1371/journal.pone. 0077730

75. Pohlit H, Bellinghausen I, Schomer M, Heydenreich B, Saloga J, Frey H. Biodegradable pH-sensitive poly(ethylene glycol) nanocarriers for allergen encapsulation and controlled release. Biomacromolecules (2015) 16(10):3103-11. doi:10.1021/acs.biomac.5b00458

76. Liu Z, Guo H, Wu Y, Yu H, Yang H, Li J. Local nasal immunotherapy: efficacy of Dermatophagoides farinae-chitosan vaccine in murine asthma. Int Arch Allergy Immunol (2009) 150(3):221-8. doi:10.1159/000222674

77. Hall G, Lund L, Lamb JR, Jarman ER. Kinetics and mode of peptide delivery via the respiratory mucosa determine the outcome of activation versus TH2 immunity in allergic inflammation of the airways. J Allergy Clin Immunol (2002) 110(6):883-90. doi:10.1067/mai.2002.129800

78. Chew JL, Wolfowicz CB, Mao HQ, Leong KW, Chua KY. Chitosan nanoparticles containing plasmid DNA encoding house dust mite allergen, Der $\mathrm{p} 1$ for oral vaccination in mice. Vaccine (2003) 21(21-22):2720-9. doi:10.1016/ S0264-410X(03)00228-7

79. Li GP, Liu ZG, Liao B, Zhong NS. Induction of Th1-type immune response by chitosan nanoparticles containing plasmid DNA encoding house dust mite allergen Der p 2 for oral vaccination in mice. Cell Mol Immunol (2009) 6(1):45-50. doi:10.1038/cmi.2009.6

80. Roy K, Mao HQ, Huang SK, Leong KW. Oral gene delivery with chitosan DNA nanoparticles generates immunologic protection in a murine model of peanut allergy. Nat Med (1999) 5(4):387-91. doi:10.1038/7385

81. Reboucas Jde S, Irache JM, Camacho AI, Esparza I, Del Pozo V, Sanz ML, et al. Development of poly(anhydride) nanoparticles loaded with peanut proteins: the influence of preparation method on the immunogenic properties. Eur J Pharm Biopharm (2012) 82(2):241-9. doi:10.1016/j.ejpb.2012.06.014
82. Zhang F, Smolen JA, Zhang S, Li R, Shah PN, Cho S, et al. Degradable polyphosphoester-based silver-loaded nanoparticles as therapeutics for bacterial lung infections. Nanoscale (2015) 7(6):2265-70. doi:10.1039/ C4NR07103D

83. Nouri HR, Varasteh A, Jaafari MR, Davies JM, Sankian M. Induction of a Th1 immune response and suppression of $\operatorname{IgE}$ via immunotherapy with a recombinant hybrid molecule encapsulated in liposome-protamine-DNA nanoparticles in a model of experimental allergy. Immunol Res (2015) 62(3):280-91. doi:10.1007/s12026-015-8659-8

84. Pali-Scholl I, Szollosi H, Starkl P, Scheicher B, Stremnitzer C, Hofmeister A, et al. Protamine nanoparticles with CpG-oligodeoxynucleotide prevent an allergen-induced Th2-response in BALB/c mice. Eur J Pharm Biopharm (2013) 85(3 Pt A):656-64. doi:10.1016/j.ejpb.2013.03.003

85. Pawankar R. Allergic diseases and asthma: a global public health concern and a call to action. World Allergy Organ J (2014) 7(1):12. doi:10.1186/19394551-7-12

86. Braido F, Arcadipane F, Marugo F, Hayashi M, Pawankar R. Allergic rhinitis: current options and future perspectives. Curr Opin Allergy Clin Immunol (2014) 14(2):168-76. doi:10.1097/ACI.0000000000000043

87. Stemeseder T, Klinglmayr E, Moser S, Lueftenegger L, Lang R, Himly M, et al. Cross-sectional study on allergic sensitization of Austrian adolescents using molecule-based IgE profiling. Allergy (2016) 72:754-63. doi:10.1111/ all.13071

88. Abbas AK, Lichtman AH, Pillai S. Cellular and Molecular Immunology. Philadelphia, PA: Elsevier Saunders (2012).

89. Demoly P, Tanno LK, Akdis CA, Lau S, Calderon MA, Santos AF, et al. Global classification and coding of hypersensitivity diseases - an EAACI - WAO survey, strategic paper and review. Allergy (2014) 69(5):559-70. doi:10.1111/ all.12386

90. Schulz O, Laing P, Sewell HF, Shakib F. Der p I, a major allergen of the house dust mite, proteolytically cleaves the low-affinity receptor for human IgE (CD23). Eur J Immunol (1995) 25(11):3191-4. doi:10.1002/eji.1830251131

91. Schulz O, Sewell HF, Shakib F. Proteolytic cleavage of CD25, the alpha subunit of the human $\mathrm{T}$ cell interleukin 2 receptor, by Der $\mathrm{p} 1$, a major mite allergen with cysteine protease activity. J Exp Med (1998) 187(2):271-5. doi:10.1084/ jem.187.2.271

92. Shakib F, Schulz O, Sewell H. A mite subversive: cleavage of CD23 and CD25 by Der $\mathrm{p} 1$ enhances allergenicity. Immunol Today (1998) 19(7):313-6. doi:10.1016/S0167-5699(98)01284-5

93. Wan H, Winton HL, Soeller C, Tovey ER, Gruenert DC, Thompson PJ, et al. Der $\mathrm{p} 1$ facilitates transepithelial allergen delivery by disruption of tight junctions. J Clin Invest (1999) 104(1):123-33. doi:10.1172/JCI5844

94. Shreffler WG, Castro RR, Kucuk ZY, Charlop-Powers Z, Grishina G, Yoo S, et al. The major glycoprotein allergen from Arachis hypogaea, Ara $\mathrm{h} \mathrm{1}$, is a ligand of dendritic cell-specific ICAM-grabbing nonintegrin and acts as a Th2 adjuvant in vitro. JImmunol (2006) 177(6):3677-85. doi:10.4049/ jimmunol.177.6.3677

95. Trompette A, Divanovic S, Visintin A, Blanchard C, Hegde RS, Madan $\mathrm{R}$, et al. Allergenicity resulting from functional mimicry of a toll-like receptor complex protein. Nature (2009) 457(7229):585-8. doi:10.1038/ nature 07548

96. Hsu SC, Chen CH, Tsai SH, Kawasaki H, Hung CH, Chu YT, et al. Functional interaction of common allergens and a C-type lectin receptor, dendritic cell-specific ICAM3-grabbing non-integrin (DC-SIGN), on human dendritic cells. J Biol Chem (2010) 285(11):7903-10. doi:10.1074/jbc.M109.058370

97. Ziegler SF, Artis D. Sensing the outside world: TSLP regulates barrier immunity. Nat Immunol (2010) 11(4):289-93. doi:10.1038/ni.1852

98. Machado Y, Freier R, Scheiblhofer S, Thalhamer T, Mayr M, Briza P, et al. Fold stability during endolysosomal acidification is a key factor for allergenicity and immunogenicity of the major birch pollen allergen. J Allergy Clin Immunol (2016) 137(5):1525-34. doi:10.1016/j.jaci.2015.09.026

99. Vercelli D. Mechanisms of the hygiene hypothesis - molecular and otherwise. Curr Opin Immunol (2006) 18(6):733-7. doi:10.1016/j.coi.2006.09.002

100. Puxeddu I, Ribatti D, Crivellato E, Levi-Schaffer F. Mast cells and eosinophils: a novel link between inflammation and angiogenesis in allergic diseases. J Allergy Clin Immunol (2005) 116(3):531-6. doi:10.1016/j.jaci.2005.06.007

101. Diaz-Sanchez D, Tsien A, Fleming J, Saxon A. Combined diesel exhaust particulate and ragweed allergen challenge markedly enhances human in vivo 
nasal ragweed-specific IgE and skews cytokine production to a T helper cell 2-type pattern. J Immunol (1997) 158(5):2406-13.

102. Knox RB, Suphioglu C, Taylor P, Desai R, Watson HC, Peng JL, et al. Major grass pollen allergen Lol $\mathrm{p} 1$ binds to diesel exhaust particles: implications for asthma and air pollution. Clin Exp Allergy (1997) 27(3):246-51. doi:10.1046/ j.1365-2222.1997.d01-508.x

103. Brandt EB, Biagini Myers JM, Acciani TH, Ryan PH, Sivaprasad U, Ruff B, et al. Exposure to allergen and diesel exhaust particles potentiates secondary allergen-specific memory responses, promoting asthma susceptibility. J Allergy Clin Immunol (2015) 136(2):295-303.e7. doi:10.1016/j.jaci.2014.11.043

104. Miller RL, Peden DB. Environmental effects on immune responses in patients with atopy and asthma. JAllergy Clin Immunol (2014) 134(5):1001-8. doi:10.1016/j.jaci.2014.07.064

105. Brandt EB, Myers JM, Ryan PH, Hershey GK. Air pollution and allergic diseases. Curr Opin Pediatr (2015) 27(6):724-35. doi:10.1097/ MOP.0000000000000286

106. Hussain S, Vanoirbeek JA, Luyts K, De Vooght V, Verbeken E, Thomassen LC, et al. Lung exposure to nanoparticles modulates an asthmatic response in a mouse model. Eur Respir J (2011) 37(2):299-309. doi:10.1183/09031936. 00168509

107. Brandenberger C, Rowley NL, Jackson-Humbles DN, Zhang Q, Bramble LA, Lewandowski RP, et al. Engineered silica nanoparticles act as adjuvants to enhance allergic airway disease in mice. Part Fibre Toxicol (2013) 10:26. doi:10.1186/1743-8977-10-26

108. Smulders S, Golanski L, Smolders E, Vanoirbeek J, Hoet PH. Nano-TiO2 modulates the dermal sensitization potency of dinitrochlorobenzene after topical exposure. Br J Dermatol (2015) 172(2):392-9. doi:10.1111/bjd.13295

109. Wang X, Podila R, Shannahan JH, Rao AM, Brown JM. Intravenously delivered graphene nanosheets and multiwalled carbon nanotubes induce site-specific Th2 inflammatory responses via the IL-33/ST2 axis. Int J Nanomedicine (2013) 8:1733-48. doi:10.2147/IJN.S44211

110. Ryan JJ, Bateman HR, Stover A, Gomez G, Norton SK, Zhao W, et al. Fullerene nanomaterials inhibit the allergic response. J Immunol (2007) 179(1):665-72. doi:10.4049/jimmunol.179.1.665

111. Laverny G, Casset A, Purohit A, Schaeffer E, Spiegelhalter C, de Blay F, et al. Immunomodulatory properties of multi-walled carbon nanotubes in peripheral blood mononuclear cells from healthy subjects and allergic patients. Toxicol Lett (2013) 217(2):91-101. doi:10.1016/j.toxlet.2012.12.008

112. Boyles M, Stoehr L, Schlinkert P, Himly M, Duschl A. The significance and insignificance of carbon nanotube-induced inflammation. Fibers (2014) 2(1):45-74. doi:10.3390/fib2010045

113. Mitchell LA, Lauer FT, Burchiel SW, McDonald JD. Mechanisms for how inhaled multiwalled carbon nanotubes suppress systemic immune function in mice. Nat Nanotechnol (2009) 4(7):451-6. doi:10.1038/nnano.2009.151

114. Shen CC, Wang CC, Liao MH, Jan TR. A single exposure to iron oxide nanoparticles attenuates antigen-specific antibody production and T-cell reactivity in ovalbumin-sensitized BALB/c mice. Int J Nanomedicine (2011) 6:1229-35. doi:10.2147/IJN.S21019

115. Monopoli MP, Aberg C, Salvati A, Dawson KA. Biomolecular coronas provide the biological identity of nanosized materials. Nat Nanotechnol (2012) 7(12):779-86. doi:10.1038/nnano.2012.207

116. Radauer-Preiml I, Andosch A, Hawranek T, Luetz-Meindl U, Wiederstein M, Horejs-Hoeck J, et al. Nanoparticle-allergen interactions mediate human allergic responses: protein corona characterization and cellular responses. Part Fibre Toxicol (2016) 13(1):3. doi:10.1186/s12989-016-0113-0

117. Mottram PL, Leong D, Crimeen-Irwin B, Gloster S, Xiang SD, Meanger J, et al. Type 1 and 2 immunity following vaccination is influenced by nanoparticle size: formulation of a model vaccine for respiratory syncytial virus. $\mathrm{Mol}$ Pharm (2007) 4(1):73-84. doi:10.1021/mp060096p

118. Hardy CL, Lemasurier JS, Mohamud R, Yao J, Xiang SD, Rolland JM, et al. Differential uptake of nanoparticles and microparticles by pulmonary APC subsets induces discrete immunological imprints. JImmunol (2013) 191(10):5278-90. doi:10.4049/jimmunol.1203131

119. Wen Z-S, Xu Y-L, Zou X-T, Xu Z-R. Chitosan nanoparticles act as an adjuvant to promote both Th1 and Th2 immune responses induced by ovalbumin in mice. Mar Drugs (2011) 9(6):1038. doi:10.3390/md9061038

120. Ferrer M, Sanz ML, Sastre J, Bartra J, del Cuvillo A, Montoro J, et al. Molecular diagnosis in allergology: application of the microarray technique. J Investig Allergol Clin Immunol (2009) 19(Suppl 1):19-24.
121. Martinez-Aranguren R, Lizaso MT, Goikoetxea MJ, Garcia BE, CabreraFreitag P, Trellez $\mathrm{O}$, et al. Is the determination of specific IgE against components using ISAC 112 a reproducible technique? PLoS One (2014) 9(2):e88394. doi:10.1371/journal.pone.0088394

122. Matricardi PM, Kleine-Tebbe J, Hoffmann HJ, Valenta R, Hilger C, Hofmaier S, et al. EAACI molecular allergology user's guide. Pediatr Allergy Immunol (2016) 27(Suppl 23):1-250. doi:10.1111/pai.12563

123. Stringari G, Tripodi S, Caffarelli C, Dondi A, Asero R, Di Rienzo Businco A, et al. The effect of component-resolved diagnosis on specific immunotherapy prescription in children with hay fever. J Allergy Clin Immunol (2014) 134(1): 75-81. doi:10.1016/j.jaci.2014.01.042

124. Asarnoj A, Hamsten C, Waden K, Lupinek C, Andersson N, Kull I, et al. Sensitization to cat and dog allergen molecules in childhood and prediction of symptoms of cat and dog allergy in adolescence: a BAMSE/MeDALL study. J Allergy Clin Immunol (2016) 137(3): 813-21.e7. doi:10.1016/j.jaci. 2015.09.052

125. Noon L. Prophylactic inoculation against hay fever. Lancet (1911) 1:1572-3. doi:10.1016/S0140-6736(00)78276-6

126. Larche M, Akdis CA, Valenta R. Immunological mechanisms of allergenspecific immunotherapy. Nat Rev Immunol (2006) 6(10):761-71. doi:10.1038/ nri1934

127. Akdis CA, Akdis M. Mechanisms of allergen-specific immunotherapy. J Allergy Clin Immunol (2011) 127(1):18-27; quiz 28-19. doi:10.1016/j.jaci. 2010.11.030

128. Ramon G. Sur l'augmentation anormale de l'antitoxine chez les chevaux producteurs de serum antidiphterique. Bull Soc Centr Med Vet (1925) 101:227-34.

129. Ramon G. Procedes pour accroitre la production des antitoxines. Ann Inst Pasteur (1926) 40(1).

130. Janeway CA Jr. Approaching the asymptote? Evolution and revolution in immunology. Cold Spring Harb Symp Quant Biol (1989) 54(Pt 1):1-13. doi:10.1101/SQB.1989.054.01.003

131. Brewer JM, Alexander J. Cytokines and the mechanisms of action of vaccine adjuvants. Cytokines Cell Mol Ther (1997) 3(4):233-46.

132. O'Hagan DT, Valiante NM. Recent advances in the discovery and delivery of vaccine adjuvants. Nat Rev Drug Discov (2003) 2(9):727. doi:10.1038/ $\operatorname{nrd} 1176$

133. Reed SG, Bertholet S, Coler RN, Friede M. New horizons in adjuvants for vaccine development. Trends Immunol (2009) 30(1):23-32. doi:10.1016/j. it.2008.09.006

134. Glenny A, Pope C, Waddington $\mathrm{H}$, Wallace $\mathrm{U}$. The antigenic value of toxoid precipitated by potassium alum. J Pathol Bacteriol (1926) 29(29):31-40. doi:10.1002/path.1700290106

135. Schöll I, Boltz-Nitulescu G, Jensen-Jarolim E. Review of novel particulate antigen delivery systems with special focus on treatment of type I allergy. J Control Release (2005) 104(1):1-27. doi:10.1016/j.jconrel.2004.12.020

136. Lambrecht BN, Kool M, Willart MA, Hammad H. Mechanism of action of clinically approved adjuvants. Curr Opin Immunol (2009) 21(1):23-9. doi:10.1016/j.coi.2009.01.004

137. Aguilar JC, Rodríguez EG. Vaccine adjuvants revisited. Vaccine (2007) 25(19):3752-62. doi:10.1016/j.vaccine.2007.01.111

138. Fifis T, Gamvrellis A, Crimeen-Irwin B, Pietersz GA, Li J, Mottram PL, et al. Size-dependent immunogenicity: therapeutic and protective properties of nano-vaccines against tumors. J Immunol (2004) 173(5):3148-54. doi:10.4049/jimmunol.173.5.3148

139. Akagi T, Baba M, Akashi M. Biodegradable nanoparticles as vaccine adjuvants and delivery systems: regulation of immune responses by nanoparticle-based vaccine. Adv Polym Sci (2012) 247:31-64. doi:10.1007/12_2011_150

140. Kalkanidis M, Pietersz GA, Xiang SD, Mottram PL, Crimeen-Irwin B, Ardipradja K, et al. Methods for nano-particle based vaccine formulation and evaluation of their immunogenicity. Methods (2006) 40(1):20-9. doi:10.1016/j.ymeth.2006.05.018

141. Mercuri LP, Carvalho LV, Lima FA, Quayle C, Fantini MCA, Tanaka GS, et al. Ordered mesoporous silica SBA-15: a new effective adjuvant to induce antibody response. Small (2006) 2(2):254-6. doi:10.1002/smll. 200500274

142. Xu L, Liu Y, Chen Z, Li W, Liu Y, Wang L, et al. Surface-engineered gold nanorods: promising DNA vaccine adjuvant for HIV-1 treatment. Nano Lett (2012) 12(4):2003-12. doi:10.1021/nl300027p 
143. Olbrich C, Kayser O, Müller R, Grubhofer N. Solid lipid nanoparticles (SLN) as vaccine adjuvant - study in sheep with a mycoplasma bovis antigen and stability testing. Intern Symp Control Rel Bioact Mater (2000) 27:8110.

144. Wheeler AW, Woroniecki SR. Immunological adjuvants in allergy vaccines: past, present future. Allergol Int (2001) 50(4):295-301. doi:10.1046/j.14401592.2001.00230.x

145. Francis JN, Durham SR. Adjuvants for allergen immunotherapy: experimental results and clinical perspectives. Curr Opin Allergy Clin Immunol (2004) 4(6):543-8. doi:10.1097/00130832-200412000-00012

146. Uto T, Akagi T, Toyama M, Nishi Y, Shima F, Akashi M, et al. Comparative activity of biodegradable nanoparticles with aluminum adjuvants: antigen uptake by dendritic cells and induction of immune response in mice. Immunol Lett (2011) 140(1-2):36-43. doi:10.1016/j.imlet.2011.06.002

147. Csaba N, Garcia-Fuentes M, Alonso MJ. Nanoparticles for nasal vaccination. Adv Drug Deliv Rev (2009) 61(2):140-57. doi:10.1016/j.addr.2008.09.005

148. Uto T, Wang X, Sato K, Haraguchi M, Akagi T, Akashi M, et al. Targeting of antigen to dendritic cells with poly( $\gamma$-glutamic acid) nanoparticles induces antigen-specific humoral and cellular immunity. J Immunol (2007) 178(5):2979-86. doi:10.4049/jimmunol.178.5.2979

149. Maini RN, Taylor PC. Anti-cytokine therapy for rheumatoid arthritis. Annu Rev Med (2000) 51:207-29. doi:10.1146/annurev.med.51.1.207

150. van den Berg WB. Anti-cytokine therapy in chronic destructive arthritis. Arthritis Res (2001) 3(1):18-26. doi:10.1186/ar136

151. Guo J, Jiang X, Gui S. RNA interference-based nanosystems for inflammatory bowel disease therapy. Int J Nanomedicine (2016) 11:5287-310. doi:10.2147/ IJN.S116902

152. Thompson C, Davies R, Choy E. Anti cytokine therapy in chronic inflammatory arthritis. Cytokine (2016) 86:92-9. doi:10.1016/j.cyto.2016.07.015

153. Owens DE III, Peppas NA. Opsonization, biodistribution, and pharmacokinetics of polymeric nanoparticles. Int J Pharm (2006) 307(1):93-102. doi:10.1016/j.ijpharm.2005.10.010

154. Duncan R. Polymer therapeutics as nanomedicines: new perspectives. Curr Opin Biotechnol (2011) 22(4):492-501. doi:10.1016/j.copbio.2011.05.507

155. Bousquet J, Lockey R, Malling HJ, Alvarez-Cuesta E, Canonica GW, Chapman MD, et al. Allergen immunotherapy: therapeutic vaccines for allergic diseases. World Health Organization. American Academy of Allergy, Asthma and Immunology. Ann Allergy Asthma Immunol (1998) 81(5):401-5. doi:10.1016/S1081-1206(10)63136-5

156. Marsh DG, Norman PS, Roebber M, Lichtenstein LM. Studies on allergoids from naturally occurring allergens. III. Preparation of ragweed pollen allergoids by aldehyde modification in two steps. J Allergy Clin Immunol (1981) 68(6):449-59. doi:10.1016/0091-6749(81)90199-8

157. Grammer LC, Shaughnessy MA, Patterson R. Modified forms of allergen immunotherapy. JAllergy Clin Immunol (1985) 76(2 Pt 2):397-401. doi:10.1016/0091-6749(85)90661-X

158. Maasch HJ, Marsh DG. Standardized extracts modified allergens - allergoids. Clin Rev Allergy (1987) 5(1):89-106. doi:10.1007/BF02802259

159. Ferreira F, Ebner C, Kramer B, Casari G, Briza P, Kungl AJ, et al. Modulation of $\mathrm{IgE}$ reactivity of allergens by site-directed mutagenesis: potential use of hypoallergenic variants for immunotherapy. FASEB J (1998) 12(2):231-42.

160. Casanovas M, Fernandez-Caldas E, Alamar R, Basomba A. Comparative study of tolerance between unmodified and high doses of chemically modified allergen vaccines of Dermatophagoides pteronyssinus. Int Arch Allergy Immunol (2005) 137(3):211-8. doi:10.1159/000086333

161. Lund L, Henmar H, Wurtzen PA, Lund G, Hjortskov N, Larsen JN. Comparison of allergenicity and immunogenicity of an intact allergen vaccine and commercially available allergoid products for birch pollen immunotherapy. Clin Exp Allergy (2007) 37(4):564-71. doi:10.1111/j.1365-2222.2007.02687.x

162. Henmar H, Lund G, Lund L, Petersen A, Wurtzen PA. Allergenicity, immunogenicity and dose-relationship of three intact allergen vaccines and four allergoid vaccines for subcutaneous grass pollen immunotherapy. Clin Exp Immunol (2008) 153(3):316-23. doi:10.1111/j.1365-2249.2008.03710.x

163. Novak N, Bieber T, Allam JP. Immunological mechanisms of sublingual allergen-specific immunotherapy. Allergy (2011) 66(6):733-9. doi:10.1111/j. 1398-9995.2010.02535.x

164. Scheiblhofer S, Machado Y, Feinle A, Thalhamer J, Husing N, Weiss R. Potential of nanoparticles for allergen-specific immunotherapy - use of silica nanoparticles as vaccination platform. Expert Opin Drug Deliv (2016) 13(12):1777-88. doi:10.1080/17425247.2016.1203898
165. Gomez S, Gamazo C, San Roman B, Vauthier C, Ferrer M, Irachel JM. Development of a novel vaccine delivery system based on Gantrez nanoparticles. J Nanosci Nanotechnol (2006) 6(9-10):3283-9. doi:10.1166/jnn.2006.471

166. Roman BS, Espuelas S, Gomez S, Gamazo C, Sanz ML, Ferrer M, et al. Intradermal immunization with ovalbumin-loaded poly-epsilon-caprolactone microparticles conferred protection in ovalbumin-sensitized allergic mice. Clin Exp Allergy (2007) 37(2):287-95. doi:10.1111/j.1365-2222.2007.02654.x

167. Pandey RS, Sahu S, Sudheesh MS, Madan J, Kumar M, Dixit VK. Carbohydrate modified ultrafine ceramic nanoparticles for allergen immunotherapy. Int Immunopharmacol (2011) 11(8):925-31. doi:10.1016/j.intimp.2011.02.004

168. Kawakita A, Shirasaki H, Yasutomi M, Tokuriki S, Mayumi M, Naiki H, et al. Immunotherapy with oligomannose-coated liposomes ameliorates allergic symptoms in a murine food allergy model. Allergy (2012) 67(3):371-9. doi:10.1111/j.1398-9995.2011.02777.x

169. Weinberger EE, Himly M, Myschik J, Hauser M, Altmann F, Isakovic A, et al. Generation of hypoallergenic neoglycoconjugates for dendritic cell targeted vaccination: a novel tool for specific immunotherapy. J Control Release (2013) 165(2):101-9. doi:10.1016/j.jconrel.2012.11.002

170. Landesman-Milo D, Peer D. Altering the immune response with lipid-based nanoparticles. J Control Release (2012) 161(2):600-8. doi:10.1016/j.jconrel. 2011.12.034

171. DeTemmerman M-L, RejmanJ,DemeesterJ,IrvineDJ, Gander B, DeSmedtSC. Particulate vaccines: on the quest for optimal delivery and immune response. Drug Discov Today (2011) 16(13-14):569-82. doi:10.1016/j.drudis. 2011.04.006

172. Goldsmith M, Mizrahy S, Peer D. Grand challenges in modulating the immune response with RNAi nanomedicines. Nanomedicine (2011) 6(10):1771-85. doi:10.2217/nnm.11.162

173. Peer D, Park EJ, Morishita Y, Carman CV, Shimaoka M. Systemic leukocytedirected siRNA delivery revealing cyclin D1 as an anti-inflammatory target. Science (2008) 319(5863):627-30. doi:10.1126/science.1149859

174. Kedmi R, Ben-Arie N, Peer D. The systemic toxicity of positively charged lipid nanoparticles and the role of toll-like receptor 4 in immune activation. Biomaterials (2010) 31(26):6867-75. doi:10.1016/j.biomaterials.2010.05.027

175. Yazdi AS, Guarda G, Riteau N, Drexler SK, Tardivel A, Couillin I, et al. Nanoparticles activate the NLR pyrin domain containing 3 (Nlrp3) inflammasome and cause pulmonary inflammation through release of IL- $1 \alpha$ and IL-1 1. Proc Natl Acad Sci U S A (2010) 107(45):19449-54. doi:10.1073/ pnas. 1008155107

176. Dobrovolskaia MA, McNeil SE. Immunological properties of engineered nanomaterials. Nat Nanotechnol (2007) 2(8):469-78. doi:10.1038/ nnano.2007.223

177. Zolnik BS, González-Fernández Á, Sadrieh N, Dobrovolskaia MA. Minireview: nanoparticles and the immune system. Endocrinology (2010) 151(2):458-65. doi:10.1210/en.2009-1082

178. Blanco E, Shen H, Ferrari M. Principles of nanoparticle design for overcoming biological barriers to drug delivery. Nat Biotechnol (2015) 33(9):941-51. doi: $10.1038 /$ nbt. 3330

179. MacParland SA, Tsoi KM, Ouyang B, Ma XZ, Manuel J, Fawaz A, et al. Phenotype determines nanoparticle uptake by human macrophages from liver and blood. ACS Nano (2017) 11(3):2428-43. doi:10.1021/acsnano.6b06245

180. Lutsiak MEC, Kwon GS, Samuel J. Biodegradable nanoparticle delivery of a Th2-biased peptide for induction of Th1 immune responses. JPharm Pharmacol (2006) 58(6):739-47. doi:10.1211/jpp.58.6.0004

181. Mowat AM, Maloy KJ, Donachie AM. Immune-stimulating complexes as adjuvants for inducing local and systemic immunity after oral immunization with protein antigens. Immunology (1993) 80(4):527-34.

182. Tighe H, Takabayashi K, Schwartz D, Van Nest G, Tuck S, Eiden JJ, et al. Conjugation of immunostimulatory DNA to the short ragweed allergen amb a 1 enhances its immunogenicity and reduces its allergenicity. J Allergy Clin Immunol (2000) 106(1 Pt 1):124-34. doi:10.1067/mai.2000.107927

183. Simons FE, Shikishima Y, Van Nest G, Eiden JJ, HayGlass KT. Selective immune redirection in humans with ragweed allergy by injecting Amb a 1 linked to immunostimulatory DNA. JAllergy Clin Immunol (2004) 113(6):1144-51. doi:10.1016/j.jaci.2004.03.003

184. Tulic MK, Fiset PO, Manoukian JJ, Frenkiel S, Lavigne F, Eidelman DH, et al. Role of toll-like receptor 4 in protection by bacterial lipopolysaccharide in the nasal mucosa of atopic children but not adults. Lancet (2004) 363(9422):1689-97. doi:10.1016/S0140-6736(04)16253-3 
185. Creticos PS, Schroeder JT, Hamilton RG, Balcer-Whaley SL, Khattignavong AP, Lindblad R, et al. Immunotherapy with a ragweed-toll-like receptor 9 agonist vaccine for allergic rhinitis. N Engl J Med (2006) 355(14):1445-55. doi:10.1056/NEJMoa052916

186. Pfaar O, Barth C, Jaschke C, Hormann K, Klimek L. Sublingual allergenspecific immunotherapy adjuvanted with monophosphoryl lipid A: a phase I/IIa study. Int Arch Allergy Immunol (2011) 154(4):336-44. doi:10.1159/ 000321826

187. Marciani DJ. New Th2 adjuvants for preventive and active immunotherapy of neurodegenerative proteinopathies. Drug Discov Today (2014) 19(7): 912-20. doi:10.1016/j.drudis.2014.02.015

188. Himly M, Grotz B, Sageder M, Geppert M, Duschl A. Immune frailty and nanomaterials: the case of allergies. Curr Bionanotechnol (2016) 2(1):20-8. doi:10.2174/2213529402666160601124654
Conflict of Interest Statement: The authors declare that the research was conducted in the absence of any commercial or financial relationships that could be construed as a potential conflict of interest.

The reviewer, JS, and handling Editor declared their shared affiliation, and the handling editor states that the process nevertheless met the standards of a fair and objective review.

Copyright (๑) 2017 Himly, Mills-Goodlet, Geppert and Duschl. This is an open-access article distributed under the terms of the Creative Commons Attribution License (CC BY). The use, distribution or reproduction in other forums is permitted, provided the original author(s) or licensor are credited and that the original publication in this journal is cited, in accordance with accepted academic practice. No use, distribution or reproduction is permitted which does not comply with these terms. 